\title{
RESIDENTS' ATTITUDE TOWARD TOURISM IN ZWIERZYNIEC TOWN
}

\author{
ANDRZEJ TUCKI, ${ }^{1}$ ANJA TUOHINO ${ }^{2}$ \\ ${ }^{1}$ Uniwersytet Marii Curie-Skłodowskiej, POLAND \\ e-mail: andrzej.tucki@umcs.pl \\ ${ }^{2}$ University of Eastern Finland, Centre for Tourism Studies, FINLAND \\ e-mail: anja.tuohino@uef.fi
}

KEYWORDS | socioeconomic impacts; resident attitudes, tourism development, factor analysis

ABSTRACT In recent years, tourism has been playing a more significant role in the economies of Poland, including rural areas, especially in eastern Poland. Therefore, tourism development and management are being integrated with community planning and development, including stakeholders' perception and opinion on tourism. The purpose of the paper is to examine attitudes of residents of small tourist destination toward tourism development. Factor analysis of scaled items measuring their attitudes resulted in four tourism-related factors: Negative social and cultural impact, Affirmative of tourism development, Economic and social benefits and and stronger sense of belonging, Nature and culture conservations. The results indicate that there is a relationship between residents' affirmation of tourism development and employment in tourism industry.

\section{Introduction}

Many communities encourage the development of tourism as a means to improve the quality of life for residents. The main focus of development activities usually lies in the economic benefits the industry can bring to the community in the form of tax revenues, jobs, and additional sources of income (e.g Andereck, Nyaupane, 2011). It is also accepted that the long-term success of tourism development is likely to be achieved when the local residents' views are considered and taken into 
account in the development process (e.g. Lundberg, 2015). Therefore, tourism development and management are being integrated with community planning and development. Research into the antecedents of resident reaction to tourism can also help planners (Brida et al., 2010; McDowall, Choi, 2010). If it is known why residents support or oppose the tourism industry, it will be possible to select those developments which can minimize negative social impacts and maximize support for such alternatives. As such, quality of life for residents can be enhanced, or at least maintained, with respect to the impact of tourism in the community. Therefore, it is not very surprising that research on residents' reactions continues to be a topic of considerable interest (Ko, Stewart, 2002; Nuunko et al., 2010; Uysal, et al., 2012; Lundberg, 2015).

There are many studies dealing with residents' attitudes towards tourism and their associated impacts. Some of these studies have used different approaches to explore residents' socio-demographic characteristics (e.g. primarily age, gender, education and income) and their behaviours regarding the tourism industry (Brunt, Courtney, 1999; Kuvan, Akan, 2005; Lawson et al., 1998; Sharma, Dyer, 2009). These studies have spread to different destinations across various countries. However, a significant number of them have been made in the USA, that is to say, much of this research has been limited to case studies in the developed world and specifically in places where rural tourism or leisure areas is focused (Nunkoo, Gursoy, 2012). Likewise, a lack of attention to these studies in destinations such as the Mediterranean and the Caribbean, where tourism is the economic base of residents, has been observed (Pérez, Nadal, 2005).

As residents are an integral part of the cultural tourism phenomenon, they can also be a determinant of the success of a tourism destination. This potential has been underlined, since the end of the 1970s by Pizam (1978) and in the early 1980s by Brougham and Butler (1981). In the first half of the 1990s, other relevant studies about these issues were produced (Ap, 1992; Getz, 1994). A great deal of research has been carried out on the residents' perceptions of both the negative and positive impacts of tourism on host communities (McDowall, Choi, 2010; Pizam, 1978; Sharma, Dyer, 2009). These impacts can be economic, sociocultural, physiological or environmental (Nunkoo, Ramkissoon, 2011).

There are many factors involved in residents' attitudes and responses to tourism impacts. The most relevant being socio-demographics, the proximity of tourism attractions to residential areas, the local economic relevance of the tourism industry, as well as the type, scale and scope of the tourism activity ( Kuvan, Akan, 2005; Sharma, Dyer, 2009; Williams, Lawson, 2001).

Many studies (Choi, Sirakaya, 2005; Kuvan, Akan, 2005; Nunkoo et al., 2010) confirm that residents who succeed in benefiting from a tourism activity tend to support its development. Those who derive little or no benefit from tourism tend to oppose to it. Relatively up to date, few research studies have been carried out in Poland on residents' perceptions of tourism impacts (e.g. Gogolewska, 1990; Komorowska, 2003; Mazurkiewicz, Kowalczyk, 2008; Tucki, Soszyński, 2012; Tucki, Vargas-Sanchez, 2012; Niezgoda, 2006, 2011). Against this backdrop, this paper is geared towards bridging the gap in polish literature by exploring the impact and attitude to tourism by local community of Zwierzyniec town. It aims to assess the residents of Zwierzyniec according to their tourism impact perceptions. 


\section{Material and reseanch methods}

The analysis covered Zwierzyniec, located in east-central Poland in the Lubelskie Province. Its tourist traditions date back to the $16^{\text {th }}$ century, when the summer residence of the Zamoyski Estate was established here, and they are continued today. The tourist attractiveness of Zwierzyniec is determined by: its location in a zone with the highest values of the natural environment in the Lublin region existing recreational values; high value of the cultural environment, as well as longstanding tourist traditions of the town. It is one of the most important tourist destination distinguished by the highest tourist potential at the scale of the whole Lublin region (Tucki, 2009).

Zwierzyniec is a small town with approximately 3,400 residents (Lubelskie Province, 2013). From the late 1970's (with the establishment of the Roztocze National Park and gradual development of tourist infrastructure), services, including tourist services, have had an increasing effect on the character of its economy. The more recent increase in tourist numbers has its origins in the success of a FART film festival (since 2004). In 2014, out of a total of 309 economic entities functioning in Zwierzyniec, 176 companies providing services were recorded (57\%), including 46 entities (15\%) in an accommodation and gastronomy section (http://lublin.stat.gov.pl/cps/rde/xbcr/ lublin/ASSETS_13p16.pdf).

According to data of the Municipal Office in Zwierzyniec, in June 2014, the town featured 83 accommodation establishments $(83.8 \%$ of the accommodation base of the commune) with approximately 2000 accommodation places. Private accommodation objects were dominant (private apartments and rooms to let). Only five of them were collective accommodation ones (with 231 accommodation places). Tourism in this area is highly seasonal, concentrated in a few summer months (end June-end August), and the destinations have a large number of second home owners.

Taking into account the objectives underlined, the data collection process was performed through a questionnaire distributed between June and August 2012 to a convenience sample. We distributed 300 questionnaires and 234 were returned, which meant a response rate of $65.4 \%$ of the questionnaires handed out. Only respondents that were state residents over the age of 18 were allowed to complete the survey.

The questionnaire consists of five blocks items: personal characteristics; perception of: personal benefits, impacts of tourism and tourists; relation with tourism and tourists; perception of the local community; and attitude towards additional tourism development. Except for the first part about the socio-demographic profile of residents and the level of reliance on tourism and quality of life, statements $13-50$ presented (38 items) the same response pattern: a five-point Likert scale was applied to each claim. Most of the items measured using a Likert have been extracted from the review of previous studies published by various authors, mainly those by Gursoy et al. (2002), Gursoy and Rutherford (2004), Gursoy and Kendall (2006), Vargas-Sánchez et al. (2009).

The first step was to calculate univariate statistics such as frequencies, means and standard deviations. The second step was to undertake factor analyses. Before undertaking the factor analyses, the validity of the data was tested by using the Kaiser-Meyer-Olkin test of sampling adequacy. The result of the test was a value of 0.906 , which indicates that both the number of variables and 
the sample size were appropriate for factor analyses. To test the reliability of the scale Cronbach $\alpha$ was calculated. The value of Cronbach $\alpha$ was 0.929 , exceeding the minimum standard of 0.800 and indicating satisfactory internal consistency reliability of the scale.

To determine the number of factors the criterion of eigenvalues greater than 1 was used. In the factor model, loadings of an absolute value of 0.400 or more were considered in order to load highly enough and because it was appropriate for the number of variables and sample size.

\section{Research results}

\section{Respondents' profiles}

From the total of 234 respondents, the range age of respondents were between 30 years old to 39 years old represent $22.9 \%$ of total respondent followed by range between 40 years old to 49 years old with $21.9 \%$. 20.2\% of respondents' age was between 18 years old to 29 years old. The average age of the respondents was 53.6 years old. In actual fact, most of the youth were studying as well as working at the mainland. The respondents are made up of $54.7 \%$ female and $45.3 \%$ males. Most of the respondents possess primary and secondary level education. 7,7\% of them are with a bachelor degree and $13.7 \%$ master degree. $31.2 \%$ of them were or are still working in tourism industry related jobs such as employee or entrepreneurs in the hotels, restaurants or handicraft shops, became tourist guide, as well as operating the canoeing. The majority of the respondents $(66.2 \%)$ had lived in their community for over 20 years. Another $22.2 \%$ had resided in the same locality for 11-20 years. About $11.5 \%$ reported a length of residency of 10 years or less.

\section{Genepal data}

Table 1 displays the descriptive statistics of the 36 variables. Based on a five point Likert type scale ( 1 = strongly disagree, $2=$ disagree, $3=$ neutral, $4=$ agree, and $5=$ strongly agree), the composite variable scores revealed that the four survey statements the respondents most strongly agreed with were: (a) Q25 “There are more parks and places for leisure" (M=3.96), (b) Q29 "Tourism provides an incentive for the conservation of the natural resources" $(\mathrm{M}=3.93)$, and (c) Q24 "The aspect of the locality is improved, thanks to tourism” (M=3.87), (d) Q30 Tourism provides an incentive for the maintenance and restoration of historic buildings $(\mathrm{M}=3.87)$ and Q19 Tourism is making this locality a more attractive and interesting place to live $(M=3.84)$. Whilst the three survey statements respondents most strongly disagreed with were: (a) Q39 "Prostitution and sexual permissiveness have increased" $(\mathrm{M}=1.58)$, (b) Q38 "Alcoholism has increased" $(\mathrm{M}=1.89)$, and (c) Q40 “The local labour force is exploited” $(\mathrm{M}=1.91)$. 
Table 1. Overall responses to perceived impacts of tourism

\begin{tabular}{|c|c|c|c|c|c|c|c|}
\hline \multirow{3}{*}{ Impact items } & Strong & ly disag & & Strongly & gree & \multirow{3}{*}{ Mean } & \multirow{3}{*}{$\begin{array}{c}\text { Std. } \\
\text { Deviation }\end{array}$} \\
\hline & \multicolumn{5}{|c|}{ (\% of answers) } & & \\
\hline & 1 & 2 & 3 & 4 & 5 & & \\
\hline 1 & 2 & 3 & 4 & 5 & 6 & 7 & 8 \\
\hline P13 Improvement of investment and more economic development & 6.60 & 17.18 & 42.73 & 21.14 & 12.30 & 3.15 & 1.05 \\
\hline P14 Increased opportunities for employment & 6.00 & 21.45 & 31.75 & 29.18 & 11.58 & 3.18 & 1.08 \\
\hline $\begin{array}{l}\text { P15 Contribution to improving local people's incomes and living } \\
\text { standards }\end{array}$ & 5.15 & 11.58 & 29.18 & 33.90 & 20.17 & 3.52 & 1.09 \\
\hline $\begin{array}{l}\text { P16 The money invested to attract more tourists to the locality } \\
\text { is a good investment }\end{array}$ & 5.12 & 11.96 & 27.35 & 38.46 & 17.09 & 3.50 & 1.06 \\
\hline P17 Improvement of the quality of life & 7.29 & 11.58 & 33.90 & 34.76 & 12.44 & 3.33 & 1.07 \\
\hline $\begin{array}{l}\text { P18 Greater availability of services, and of recreational and cultural } \\
\text { activities }\end{array}$ & 2.99 & 6.41 & 22.22 & 44.44 & 23.93 & 3.79 & 0.97 \\
\hline $\begin{array}{l}\text { P19 Tourism is making this locality a more attractive and interesting } \\
\text { place to live }\end{array}$ & 3.01 & 5.17 & 24.13 & 39.22 & 28.44 & 3.84 & 0.99 \\
\hline $\begin{array}{l}\text { P20 Tourism is promoting more knowledge of other cultures } \\
\text { and communities }\end{array}$ & 3.46 & 9.52 & 27.70 & 35.49 & 23.80 & 3.66 & 1.04 \\
\hline $\begin{array}{l}\text { P21 The inhabitants of the locality feel more proud to belong to it } \\
\text { (as a consequence of tourism) }\end{array}$ & 4.32 & 6.92 & 23.37 & 32.90 & 32.46 & 3.82 & 1.09 \\
\hline $\begin{array}{l}\text { P22 Improvement of the quality of service in restaurants, hotels and } \\
\text { shops of the area }\end{array}$ & 3.87 & 9.91 & 34.48 & 37.93 & 13.79 & 3.47 & 0.98 \\
\hline $\begin{array}{l}\text { P23 The opportunities for purchasing are greater in my locality, } \\
\text { thanks to tourism }\end{array}$ & 3.87 & 9.91 & 26.29 & 37.50 & 22.41 & 3.64 & 1.05 \\
\hline P24 The aspect of the locality is improved, thanks to tourism & 0.42 & 4.72 & 28.32 & 40.34 & 26.18 & 3.87 & 0.87 \\
\hline P25 There are more parks and places for leisure & 0.43 & 3.44 & 23.70 & 44.39 & 28.01 & 3.96 & 0.83 \\
\hline $\begin{array}{l}\text { P26 Improvement in the level of police protection and fire-fighting } \\
\text { services }\end{array}$ & 6.03 & 11.63 & 40.94 & 34.05 & 7.32 & 3.25 & 0.96 \\
\hline $\begin{array}{l}\text { P27 Improvement of infrastructures (water supply, electricity, } \\
\text { telephone, etc.) }\end{array}$ & 5.72 & 13.21 & 31.71 & 37.88 & 11.45 & 3.36 & 1.03 \\
\hline $\begin{array}{l}\text { P28 Tourism provides an incentive for the preservation of the local } \\
\text { culture }\end{array}$ & 0.42 & 4.29 & 29.61 & 40.77 & 24.89 & 3.85 & 0.85 \\
\hline $\begin{array}{l}\text { P29 Tourism provides an incentive for the conservation of the natural } \\
\text { resources }\end{array}$ & 0.00 & 5.60 & 26.29 & 37.50 & 30.60 & 3.93 & 0.88 \\
\hline $\begin{array}{l}\text { P30 Tourism provides an incentive for the maintenance and restora- } \\
\text { tion of historic buildings }\end{array}$ & 0.42 & 5.15 & 27.46 & 40.34 & 26.60 & 3.87 & 0.87 \\
\hline P31 The quality of public services for residents is improved & 4.82 & 10.52 & 32.45 & 39.47 & 12.71 & 3.44 & 1.00 \\
\hline P32 House prices have increased & 9.90 & 2.35 & 23.58 & 30.18 & 33.96 & 3.75 & 1.22 \\
\hline P33 The cost of living (prices of products and services) has increased & 9.33 & 2.66 & 21.33 & 35.55 & 31.11 & 3.76 & 1.19 \\
\hline P34* Tourism provides benefits for only a few residents & 32.28 & 30.94 & 29.14 & 3.13 & 4.48 & 2.16 & 1.05 \\
\hline $\begin{array}{l}\text { P35 The benefits generated by the tourism activity end up with com- } \\
\text { panies and persons from outside the locality }\end{array}$ & 15.04 & 10.19 & 32.52 & 26.69 & 15.53 & 3.17 & 1.25 \\
\hline P36 Traffic and parking problems have increased. & 31.03 & 12.93 & 23.70 & 18.10 & 14.22 & 2.71 & 1.43 \\
\hline P37 Thefts and vandalism have increased & 47.18 & 25.54 & 17.74 & 5.19 & 4.32 & 1.93 & 1.11 \\
\hline P38 Alcoholism has increased & 47.39 & 28.69 & 15.21 & 4.78 & 3.91 & 1.89 & 1.07 \\
\hline P39 Prostitution and sexual permissiveness have increased & 67.54 & 17.54 & 7.01 & 4.82 & 3.07 & 1.58 & 1.02 \\
\hline P40 The local labour force is exploited & 50.64 & 20.17 & 19.31 & 6.86 & 3.00 & 1.91 & 1.11 \\
\hline $\begin{array}{l}\text { P41 There have been changes and losses in the traditional way of life } \\
\text { and culture }\end{array}$ & 47.84 & 20.25 & 16.81 & 11.20 & 3.87 & 2.03 & 1.20 \\
\hline 42 There are problems of coexistence between residents and tourists & 55.60 & 18.96 & 11.20 & 5.17 & 9.05 & 1.93 & 1.30 \\
\hline 43 The tranquillity of the area has been lost & 47.86 & 19.65 & 15.81 & 8.54 & 8.11 & 2.09 & 1.30 \\
\hline P44 The natural surroundings and countryside have been damaged & 40.08 & 25.43 & 19.82 & 6.03 & 8.62 & 2.17 & 1.26 \\
\hline
\end{tabular}




\begin{tabular}{|c|c|c|c|c|c|c|c|}
\hline 1 & 2 & 3 & 4 & 5 & 6 & 7 & 8 \\
\hline $\begin{array}{l}\text { P45 There has been unregulated growth of urban and residential } \\
\text { development }\end{array}$ & 52.42 & 17.18 & 11.89 & 9.69 & 8.81 & 2.05 & 1.35 \\
\hline P46 The traditional architecture has been destroyed & 50.21 & 20.17 & 12.87 & 8.58 & 8.15 & 2.04 & 1.30 \\
\hline $\begin{array}{l}\text { P47 Environmental pollution (rubbish, waste waters, air pollution and } \\
\text { noise) has increased }\end{array}$ & 36.75 & 23.07 & 17.94 & 9.40 & 12.82 & 2.38 & 1.39 \\
\hline $\begin{array}{l}\text { P48 The overcrowding and congestion of spaces for public use and } \\
\text { enjoyment (beaches, countryside, town squares and streets, ...) } \\
\text { is annoying }\end{array}$ & 50.42 & 20.94 & 11.53 & 5.98 & 11.11 & 2.06 & 1.36 \\
\hline P49 Public health and transport services are overloaded & 53.87 & 18.96 & 10.34 & 7.75 & 9.05 & 1.99 & 1.33 \\
\hline $\begin{array}{l}\text { P50 The quality of local services has deteriorated (long queues and } \\
\text { delays in restaurants, shops, tourist attractions) }\end{array}$ & 53.87 & 14.22 & 13.79 & 7.75 & 10.34 & 2.06 & 1.38 \\
\hline
\end{tabular}

* reverse score.

Source: own work.

Exploratory factor analysis was conducted to assess the dimensionality of the 36 items. The first factor was labelled 'negative social and cultural impact'. Factor 1 comprises 17 items $(0.917$ alpha), followed by 'affirmative of tourism development (0.910) and 'nature and culture conservations'. Economic and social benefits and stronger sense of belonging' was the fourth factor with a loading of 0.795 (|Table 2). The results showed that the Alpha coefficients of the four factors ranged from 0.795 to 0.917 , which demonstrates that the scales of the formal questionnaire have high reliability.

Table 2. Factor analysis of residents' perceptions

\begin{tabular}{lll}
\hline \multicolumn{1}{c}{ Factors } & \multicolumn{1}{c}{$\begin{array}{c}\text { Alpha } \\
\text { Coefficient }\end{array}$} & \multicolumn{1}{c}{ Items } \\
\hline Negative social and cultural impact & 0.917 & $\begin{array}{l}\text { Q36, Q37, Q38, Q39, Q40, Q41, Q42, Q43, Q44, Q45, P46, Q47, } \\
\text { Q48, Q49, Q50 }\end{array}$ \\
$\begin{array}{l}\text { Affirmative of tourism development } \\
\text { Economic and social benefits and stronger } \\
\text { sense of belonging }\end{array}$ & 0.910 & Q13 Q14, Q17, Q18 Q22 Q23 Q26 Q27 Q31 Q32 Q33 Q35 \\
Nature and culture conservations & 0.795 & Q15, Q16, Q19, Q20, Q21, Q24, Q 34 \\
\hline
\end{tabular}

Source: own work.

Table 3. Regression analysis of the relationship between variables

\begin{tabular}{lcc}
\hline \multirow{2}{*}{ Model 1} & \multicolumn{1}{c}{ Beta } & t-statistic \\
\cline { 2 - 3 } & $\begin{array}{l}\text { Concerns for Affirmative of tourism development } \\
\text { Revised } \mathrm{R}^{2}=0.078, \mathrm{~F}=5.998, \mathrm{p}=0.000\end{array}$ & -0.237 \\
\hline Q9 Work involved in tourism sector & & $-3.710^{* * *}$ \\
\hline$* * * \mathrm{p}<0.10$. & & -
\end{tabular}

Source: own work.

In order to explore the relationships between residents' socio-economic and demographic attributes and their attitudes toward tourism, multiple regression analysis was performed. Based on 
the results it can be concluded that only "working in tourism industry" has statistically significant relationships in a negative direction with Factor 2. That means, people involved in tourism sector don't see many benefits as tourism is coming into the town.

\section{Conclusions}

The aim of this paper was in bridging the gap in polish literature, by exploring the impact and attitude to tourism by local community of Zwierzyniec town. In general, the results follow the findings of the earlier research and both positive and negative impacts were found. The average profile of the respondents was as follows; female, about 53 years old with primary and secondary level education, one third working in the tourism-related industry, and with a long living in their community. The study results indicated that most respondents are not much favorable toward tourism. The results of this study illustrated that residents are aware of the benefits, as well as the problems caused by tourism. Furthermore, ranking of the mean responses for each dimension in the study showed that respondents expressed the highest level of agreement with the statements that tourism provides an incentive for the conservation of the natural resources and there are more leisure area thanks to tourism. The results showed that working in tourism industry have significantly less positive attitude towards tourism development compared to the residents not involved in that sector, which is not very typical for the research of the attitudes of local residents in other regions. But as stated in literature (Andereck, Vogt, 2000; Vargas-Sanchez et al., 2009), it is not only the level of tourism development that influences perceptions of tourism impacts, but also what type of tourism is developed (e.g. sustainable vs. unsustainable tourism). As results show, there is not much about residents' economy and the money tourism brings, which might be caused by seasonality of the services (tourism is for only 3-4 months there which are cycling, bathing, walking, kayaking). The majority of accommodation services provided as bed and breakfast and rooms to let are also seasonal one, which all might be too short so they "see" he economy benefits tourists bring. Our results show that negative impact such as alcoholism, vandalism are ranking very low, which might be explained by exploration stage of tourism development in the area and "sustainability oriented" tourists visiting the town.

The findings of this study cannot be universalized because of the unique settings of this destination. Therefore additional analysis and the related attitudes might provide valuable contributions to resident attitudes' literature in Poland and CE Europe.

\section{References}

Andereck, K.L., Nyaupane, G.P. (2011). Exploring the Nature of Tourism and Quality of Life Perceptions among Residents Journal of Travel Research, 50 (3), 248-260.

Andereck, K.L., Vogt, C.A. (2000). The relationship between residents' attitudes toward tourism and tourism development options. Journal of Travel Research, 39, 27-36.

Ap, J. (1992). Residents Perceptions on Tourism Impacts. Annals of Tourism Research, 19, 665-690.

Brida, J.G., Osti, L., Barquet, A. (2010). Segmenting resident perceptions towards tourism - a cluster analysis with a multinomial logit model of a mountain community. International Journal of Tourism Research, 12 (5), 591-602. 
Brougham, J., Butler, R. (1981). A segmentation analysis of resident attitudes to social impacts of tourism. Annals of Tourism Research, 7 (4), 569-590.

Brunt, P., Courtney, P. (1999). Host perceptions of sociocultural impacts. Annals of Tourism Research, 26 (3), $493-515$.

Choi, H.C., Sirakaya, E. (2005). Measuring Residents' Attitude toward Sustainable Tourism: Development of Sustainable Tourism Attitude Scale. Journal of Travel Research, 43, 380-394.

Dyer, P., Gursoy, D., Sharma, B., Carter, J. (2007). Structural modeling of resident perceptions of tourism and associated development on the Sunshine Coast, Australia. Tourism Management 28, 409-422.

Getz, D. (1994). Residents' attitudes towards tourism: A longitudinal study of Spey Valley, Scotland. Tourism Management, 15 (4), 247-258.

Gogolewska, H. (1990). Zmiany kulturowe w kaszubskich wsiach turystycznych. Problemy Turystyki, 3/4.

Gursoy, D., Jurowski, C., Uysal, M. (2002). Resident attitudes - a structural modeling approach. Annals of Tourism Research, 29 (1), 79-105.

Gursoy, D., Kendall, K.W. (2006). Hosting mega events: modelling locals' support. Annals of Tourism Research, 33 (3), 603-623.

Gursoy, D., Rutherford, D.G. (2004). Host attitudes toward tourism e an improved structural model. Annals of Tourism Research, 31 (3), 495-516.

http://lublin.stat.gov.pl/cps/rde/xbcr/lublin/ASSETS_13p16.pdf (21.05.2015).

Jurowski, C., (1998). A study of community sentiments in relation to attitudes toward tourism development. Tourism Analysis, 3, 17-34.

Ko, D., Stewart, W. (2002). A structural equation model of residents' attitudes for tourism development. Tourism Management, 23, 521-530.

Komorowska, K. (2003). Turystyka a społeczności lokalne - przykład tatrzański. Studia Regionalne i Lokalne, 3, 76 -96.

Kuvan, Y., Akan, P. (2005). Residents' attitudes toward general and forest-related impacts of tourism: The case of Belek, Antalya. Tourism Management, 26, 691-706.

Lawson, R., Williams, J., Young, T., Cossens, J. (1998). A comparison of residents' attitudes towards tourism in 10 New Zealand destinations. Tourism Management, 9 (3), 247-256.

Lundberg, J. (2015). The Level of Tourism Development and Resident Attitudes: A Comparative Case Study of Coastal Destinations. Scandinavian Journal of Hospitality and Tourism. DOI: 10.1080/15022250.2015.1005335.

Mazurkiewicz, L., Kowalczyk, A. (eds.) (2008). Społeczności lokalne a turystyka. Aspekty społeczne, kulturowe, ekonomiczne. Warszawa: AWF.

McDowall, S., Choi, Y. (2010). A comparative analysis of Thailand residents' perception of tourism's impacts. Journal of Quality Assurance in Hospitality and Tourism, 11 (1), 36-55.

Niezgoda, A. (2011). Badanie opinii mieszkańców Poznania dotyczących rozwoju funkcji turystycznej (pp. 107-146). In: G. Gołembski (ed.), Sposoby mierzenia i uwarunkowania rozwoju funkcji turystycznej miasta. Poznań: Wydawnictwo Uniwersytetu Ekonomicznego.

Niezgoda, A., (2006). Rola mieszkańców obszaru recepcji turystycznej w rozwoju turystyki zrównoważonej (pp. 321330). In: S. Wodejko (ed.), Gospodarka turystyczna a grupy interesu. Warszawa: SGH.

Nunkoo, R., Gursoy, D., Juwaheer, T.D. (2010). Island Residents' Identities and their Support for Tourism: An Integration of Two Theories. Journal of Sustainable Tourism, 18 (5), 675-693.

Nunkoo, R., Ramkissoon, H. (2010). Modeling community support for a proposed integrated resort project. Journal of Sustainable Tourism, 18 (2), 257-277.

Nunkoo, R., Ramkissoon, H. (2011). Residents' satisfaction with community attributes and support for tourism. Journal of Hospitality and Tourism Research, 35 (2), 171-190.

Nunkoo, R., Gursoy, D. (2012). Residents' support for tourism: an identity perspective. Annals of Tourism Research, 39 (1), 243-268.

Pérez, E.A., Nadal, J.R. (2005). Host community perceptions: A cluster analysis. Annals of Tourism Research, 32 (4), 925-941.

Pizam, A. (1978). Tourism's impacts: the social costs to the destination community as perceived by its residents. Journal of Travel Research, 16 (4), 8-12 
Sharma, B., Dyer, P. (2009). An investigation of differences in residents' perceptions on the Sunshine Coast: tourism impacts and demographic variables. Tourism Geographies, 11 (2), 187-213.

Tucki, A. (2009). Potencjał turystyczny regionu lubelskiego. Annales UMCS, 64 (B), 11-31.

Tucki, A., Soszyński, D. (2012). Postawy społeczności lokalnej miasta Kazimierz Dolny wobec rozwoju turystyki. Problemy Ekologii Krajobrazu, 24, 245-252.

Tucki, A., Vargas-Sanches, A. (2013). Residents' attitude to tourism and their quality of life. In: Linking wellness tourism to ecosystem services: towards a research agenda. Book of Abstracts, COST Action TObeWELL, First Seminar, Wageningen, Netherlands 3-5 September 2013.

Uysal, L., Perdue, R., Sirgy, M.J. (2012). Handbook of tourism and quality of life research. London: Springer.

Vargas-Sanchez, A., Porras-Bueno, N., Angeles Plaza-Mejı'a, M. (2009). Understanding Residents' Attitudes toward the Development of Industrial Tourism in a Former Mining Community. Journal of Travel Research, 47, 373-387.

Williams, J., Lawson, R. (2001). Community issues and the resident opinions of tourism. Annals of Tourism Research, 28 (2), 269-290.

\section{EKONOMICZNE, SPOŁECZNE I ŚRODOWISKOWE KONSEKWENCJE ROZWOJU TURYSTYKI. NASTAWIENIE SPOŁECZNOŚCI LOKALNEJ DO ROZWOJU TURYSTYKI W GMINIE ZWIERZYNIEC}

SŁOWA KLUCZOWE STRESZCZENIE społeczność lokalna, nastawienie, rozwój turystyki, Zwierzyniec, analiza czynnikowa

Ostatnie lata w Polsce charakteryzują się wzrostem znaczenia usług turystycznych w gospodarce kraju, zwłaszcza na terenach wiejskich. Zrozumiałym zatem stają się analizy skutków rozwoju turystyki tak w planowaniu przestrzennym jak i strategiach zarządzania obszarem recepcji turystycznej, uwzględniające opinie interesariuszy w tym mieszkańców. Celem artykułu jest ocena postaw lokalnej społeczności miejsko-wiejskiej gminy Zwierzyniec do rozwoju turystyki. Na podstawie materiałów z przeprowadzonych wywiadów z mieszkańcami gminy przeprowadzono analizę statystyczną. W efekcie badania pozwoliły na wytypowanie czterech czynników: Negatywne skutki rozwoju turystyki w wymiarze społecznym i kulturowym, Przychylność dla rozwoju turystyki, Korzyści społeczno-ekonomiczne oraz tożsamość lokalna, Ochrona przyrody i zasobów kulturowych. Przeprowadzona analiza korelacji ze zmiennymi socjo-demograficznymi wykazała, że istnieje statystycznie istotny związek pomiędzy zatrudnieniem w sektorze turystycznym, a postawą wobec dalszego rozwoju i wspierania turystki. 